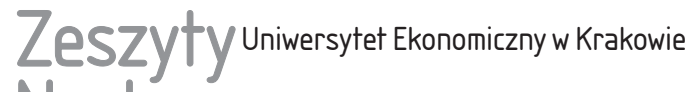 Naukowe
}

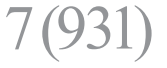

ISSN 1898-6447

Zesz. Nauk. UEK, 2014; 7 (931): 59-77

DOI: 10.15678/ZNUEK.2014.0931.0704

\section{Anna Karwińska}

Katedra Socjologii

Uniwersytet Ekonomiczny w Krakowie

\section{Cele społeczne w procesach miejskich przemian. Przykład Prądnika Czerwonego w Krakowie}

\section{Streszczenie}

Przedmiotem rozważań w artykule są działania skierowane na formułowanie i próby realizowania celów społecznych w procesach humanizacji osiedla, poprawiania jego struktury przestrzennej i społecznej. Zaprezentowano pewne ważne etapy rozwoju społeczno-przestrzennego tego obszaru, a także kolejne działania przygotowywane z inspiracji samych mieszkańców oraz władz miasta we współpracy z rozmaitymi instytucjami. Istniejące tradycje, symboliczne zasoby kulturowe, miejsca i obiekty, które mogłyby być ośrodkami społecznego skupienia, zostały częściowo zniszczone, w części uległy unieważnieniu, ponieważ nie mogły funkcjonować w nowym kontekście. Po wielu latach istnienia blokowiska niektóre z tych miejsc stały się podstawą pewnych więzi społecznych i wspólnego działania.

Słowa kluczowe: osiedle, Prądnik Czerwony, cele społeczne, smart city, przestrzeń miejska.

\section{Wprowadzenie}

Określając cele społeczne w rozwoju miasta na przykładzie krakowskiego osiedla Prądnik Czerwony, zwrócono szczególną uwagę na problemy osiągania harmonii w różnokierunkowych działaniach społeczności, a także na zagadnienia wzmacniania interakcji społecznych mieszkańców osiedla, powstawania ważnych, z punktu widzenia dobrze funkcjonującej społeczności, uwarunkowań rozwoju 
życia społecznego, możliwości realizowania wybranych stylów życia, zapewniania spójności i integracji społecznej.

$\mathrm{W}$ analizie sposobu formułowania i realizowania celów społecznych w rozwoju miasta na wybranym przykładzie bardzo istotne jest określenie kontekstu społeczno-kulturowego, w ramach którego owe ważne społeczne cele rozwojowe są definiowane, a następnie realizowane. W tym względzie obszar Prądnika Czerwonego okazał się interesujący z uwagi na specyfikę społeczno-kulturową i przestrzenną tego miejsca, a także na podejmowane w różnych okresach inicjatywy przemian, opartych na zdefiniowanych celach społecznych. Szczególnie ciekawe są dzieje tego miejsca - teren Prądnika Czerwonego był najpierw obszarem wiejskim - zapleczem dla Krakowa, następnie przedmieściem, wreszcie, po drugiej wojnie światowej, został gwałtownie przekształcony w jedno z typowych blokowisk wielkomiejskich. Powstało w ten sposób nieuładzone przestrzennie i społecznie środowisko mieszkalne, w którym mieszały się rozmaite tradycje, style życia, aspiracje. Istniejące tradycje, symboliczne zasoby kulturowe, miejsca i obiekty, które mogłyby być ośrodkami społecznego skupienia, zostały częściowo zniszczone, w części uległy unieważnieniu, ponieważ nie mogły funkcjonować w nowym kontekście. Po wielu latach istnienia blokowiska niektóre z tych miejsc niejako „odzyskały moc” w tym sensie, że stały się podstawą pewnych więzi społecznych i wspólnego działania. Tak było w przypadku omówionych w artykule wspólnych inicjatyw mieszkańców związanych z budową salek katechetycznych czy w późniejszych czasach - przyłączenia się do projektów rehabilitacji osiedla.

Główne obszary rozważań nad sposobami definiowania celów społecznych i sposobu ich osiągania w procesach humanizacji i rehabilitacji osiedla zostały zatem poprzedzone krótkim rysem historycznym pokazującym, jak kształtowała się specyfika tego obszaru.

Zastosowane w tych rozważaniach techniki badawcze to przede wszystkim analiza istniejących opracowań i dokumentacji związanych z kolejnymi próbami humanizowania i rehabilitacji osiedla. Wykorzystano także informacje pozyskane od ekspertów - członków zespołu lokalnego współdziałającego z ekspertami duńskimi w ramach projektu: Action Plan, Rehabilitation of the Urban Environment in Prqdnik Czerwony, Cracow. A Polish-Danish Pilot Project, realizowanego w latach 1991-1994. Ponadto wykorzystane zostały wyniki obserwacji w terenie prowadzonych przez studentów III roku socjologii Uniwersytetu Ekonomicznego w Krakowie w grudniu 2012 r. w oparciu o listę kategorii obserwacyjnych ${ }^{1}$.

1 W skład zespołu studentów III roku socjologii Uniwersytetu Ekonomicznego w Krakowie zbierającego i opracowującego materiały w ramach przedmiotu realizacja projektu badawczego, pod kierunkiem Magdaleny Jelonek i Anny Karwińskiej, wchodzili: Mateusz Banasik, Marcin Bugajski, Agnieszka Chruścicka, Anna Dall, Anna Kozieł, Iwona Krzywda, Beata Mazur, Jakub Stępień i Piotr Śmiłek. 


\section{Od przedmieścia do blokowiska}

Prądnik Czerwony to dawna wieś położona nad rzeką Prądnik, w XIII w. lokowana na prawie niemieckim. W tym okresie powstał zarys układu przestrzennego wzdłuż obecnej ulicy Dobrego Pasterza. Na tym terenie znajdowały się liczne dobra kościelne, folwarki szlacheckie, a także, w późniejszym okresie, posiadłości mieszczan krakowskich. Ze względu na swoje walory przyrodnicze i atrakcyjność krajobrazową Prądnik Czerwony zaczął stopniowo pełnić funkcję ,podmiejskiej miejscowości willowej” (określenie J. Bogdanowskiego), przyciągającej wiele wybitnych postaci ówczesnego życia kulturalnego. Jednocześnie obszar ten stanowił część zaplecza rolniczego i ekonomicznego Krakowa. Były tu rozmaite manufaktury: folusz, papiernia, tartak. Jak wskazywał A. Böhm [1986, s. 25], w historii tej dzielnicy pojawiały się pewne ambitne koncepcje rozwojowe, takie jak XVI-wieczny pomysł na „Stefanopolis” (ku chwale króla Stefana Batorego), miasto na wzór Kazimierza czy osada mieszczańska założona w 1639 r., której istnienie przetrwało $w$ nazwie dzielnicy Wesoła.

Od lat 50. XIX w. w Krakowie wznoszono forty i umocnienia, co z jednej strony ograniczało ekspansję urbanistyczną miasta, z drugiej zaś przyczyniło się do ożywienia gospodarczego i dostarczyło możliwości zarobku mieszkańcom przedmieść [Bieniarzówna i Małecki 1985, s. 204]. Także dla mieszkańców Prądnika Czerwonego była to okazja do znalezienia zatrudnienia w transporcie konnym i uzupełnienia w ten sposób zajęć rolniczych i rzemieślniczych. Ścisłe więzi Prądnika z Krakowem opisywał w zebranych materiałach etnograficznych z 1880 r. Władysław Tabor, wskazując na tradycje rzemieślnicze, piekarskie, ogrodnicze i rolnicze [Kraków... 1993, s. 108-109]. Jak wskazują historycy, relacje między Krakowem a przylegającymi gminami miały na przełomie XIX i XX w. charakter asymetryczny. Wiele gmin graniczących z Krakowem rozwijało się właściwie jego kosztem. Mieszkańcy korzystali ze wszystkich urządzeń i instytucji wielkomiejskich, opieki społecznej, edukacji, szpitali itp., nie przyczyniając się podatkami do wzrostu budżetu miasta. Osiedla takie jak Dębniki, Prądnik Czerwony, Podgórze miały charakter miejski [Demel 1957 s. 321-322].

Według spisu z 1869 r. Prądnik Czerwony był zamieszkały przez 827 osób i liczył 91 domów, był zatem czwartym co do wielkości przedmieściem Krakowa [Bieniarzówna i Małecki 1985, s. 231]. W miarę poprawiania się warunków życia coraz częściej osiedlali się tu przedstawiciele nierolniczych zawodów. Na przełomie XIX i XX w. ok. 3/5 mieszkańców stanowili urzędnicy, handlowcy i przemysłowcy. Jak wskazuje J. Purchla [1990, s. 30], ,opuszczali też Kraków, przenosząc się poza jego granice, sami mieszkańcy, których skłaniała do tego niezwykła drożyzna mieszkań; znaczna ilość urzędników, funkcjonariuszy prywatnych instytucji, profesorów i wojskowych, posiadających posady i wykonujących 
swój zawód w Krakowie, mieszka dla tanich mieszkań, dla położenia bliższego polom otwartym i dla tańszej żywności w Podgórzu, Dębnikach, Półwsiu Zwierzynieckim, Czarnej Wsi, Krowodrzy, w części Prądnika Czerwonego najbliżej Krakowa i w Grzegórzkach". Doceniali oni zarówno bliskość miasta, jak i urodę terenu. Było to też jedno z ulubionych miejsc przechadzek z „restauracją słynną wyborną kawą" [Estreicherówna 1968]. Tu także znajdował się jeden z najstarszych krakowskich „winogródków” - wyszynk win „Pod Czarnym Osłem”, w którym bywali „sekretarze sądu w melonikach, ale również brodaci malarze w szerokoskrzydłych kapeluszach, literaci, adwokaci, lekarze, ba, nawet szukający świeżego powietrza profesorowie Almae Matris oraz członkowie rzeczywiści Polskiej Akademii Umiejętności” [Broniewski 1970, s. 140]. Warto tu także przypomnieć, że z Prądnikiem Czerwonym związany był najsłynniejszy krakowski dorożkarz, Jan Kaczara (1907-1980). Do dziś jedna z ulic nosi jego imię.

Wspomniana wyżej funkcja garnizonowa Krakowa, w ostatecznym bilansie, mimo że narzucała pewne ograniczenia ze względu na istnienie pasu fortecznego, przyczyniła się do ożywienia handlu, przemysłu i rzemiosła. Realizacja planu Wielkiego Krakowa i dążenie do opanowania wzrastającego chaosu przestrzennego w gminach podmiejskich spowodowały przyłączenie w latach 1909-1915 13 gmin, w tym części Prądnika Czerwonego i Olszy (powstała w ten sposób XVIII dzielnica Warszawskie). Dzielnica ta posiadała znaczną liczbę terenów wojskowych, magazynów, warsztatów, pól ćwiczeń, koszary, a także cmentarz komunalny (Cmentarz Rakowicki) [Mydel 1994, s. 18].

Warto tu podkreślić, że sposób zrealizowania projektu Wielkiego Krakowa był przemyślany oraz zaplanowany i obejmował rozbudowane pertraktacje z radami gminnymi reprezentującymi mieszkańców. Oczekiwania i potrzeby mieszkańców były niemałe: mieli oni otrzymać m.in. szkołę, kanalizację, chodnik, oświetlenie gazowe, wywóz śmieci, tramwaj i własną reprezentację w Radzie Miejskiej. Można powiedzieć, że nawet obecnie mógłby to być wzór prowadzenia polityki miejskiej [Böhm 1986 s. 26].

W związku z koniecznością powiązania komunikacyjnego nowych terenów i dawnego obszaru Krakowa rozbudowano i modernizowano linie tramwajowe. Wybuch pierwszej wojny światowej uniemożliwił realizację już opracowanego planu dla Wielkiego Krakowa, jednak w latach 1912-1918 zbudowano jedno z najnowocześniejszych w owym czasie lotnisk, sukcesywnie następnie rozbudowywano kolejno: Warsztaty Lotnicze, Niższą Szkołę Pilotów, w 1923 r. otwarto Cywilną Stację Lotniczą Kraków i uruchomiono pierwszą linię lotniczą KrakówWarszawa.

W latach międzywojennych, w związku z ekonomicznym i demograficznym rozwojem Krakowa, wzrastało budownictwo mieszkaniowe zarówno w obrębie Krakowa, jak i w obszarach podmiejskich. Rozwijała się zabudowa m.in. Prąd- 
nika Czerwonego, Prądnika Białego, Prokocimia, Borku Fałęckiego realizowana w nawiązaniu do dawnych układów osadniczych. Sprzyjało to wzrostowi liczby ludności na tych obszarach coraz silniej związanych gospodarczo z miastem, rynkiem pracy czy szkolnictwem. Ta sytuacja przyspieszyła rozwój powiązań komunikacyjnych. W 1927 r. uruchomiono 13 linii łączących Kraków z obszarami peryferyjnymi, w tym np. linie Barbakan-Prądnik Czerwony, Rynek PodgórskiBorek Fałęcki, al. Słowackiego-Prądnik Biały, Mały Rynek-Rakowice-Lotnisko. W 1934 r. zbudowano linię kolejową łączącą Kraków z Warszawą, która ostatecznie rozdzieliła Biały i Czerwony Prądnik.

W okresie powojennym rozwój Prądnika Czerwonego wiązał się z budową dzielnicy Nowa Huta i dążeniem do powiązania nowych obszarów miasta w bardziej spójną całość, co oznaczało konieczność budowy infrastruktury komunikacyjnej. Sam Prądnik Czerwony stał się terenem intensywnej zabudowy osiedlowej w latach 70. XX w.

Jak wskazywał A. Böhm [1987, s. 101], obszar ten zachował bardzo długo (przez kilka wieków) swoją specyfikę i dopiero okres budowy osiedla całkowicie zmienił to dawne przedmieście Krakowa, przez zastąpienie harmonijnej całości „stylem bezpostaciowym”.

Powstało zatem typowe blokowisko, wykonane w przeważającym stopniu w technologii wielkiej płyty, posiadające liczne wady. Warto tu także wskazać, że inwestycja ta pociągnęła za sobą proces wywłaszczeń oraz przekształceń istniejącej struktury zabudowy, co doprowadziło do zupełnego niemal zaniku dawnych istniejących granic tego obszaru czy definiujących go elementów małej architektury, zieleni itp. Z drugiej strony urządzanie przestrzeni osiedlowej, tworzenie odpowiedniej infrastruktury trwało bardzo długo, co powodowało poczucie tymczasowości. Zmienił się także skład społeczny tej zbiorowości. Na kilkanaście tysięcy mieszkańców zaledwie ok. 1000 stanowiły osoby mieszkające od dawna, zazwyczaj w niewielkich domkach. W tym sensie osiedle od początku dzieliło się na dwa wyraźnie różne obszary - blokowisko i dawne przedmieście Krakowa.

Cechy charakterystyczne zespołów mieszkaniowych budowanych w tym okresie i z użyciem tych technologii poddawano niejednokrotnie krytyce, wskazując na ich główne grzechy, m.in. niestaranność wykonawstwa i niewłaściwą jakość materiałów, co przyczyniało się do szybkiej degradacji technicznej budynków.

Inną wadą były przestarzałe rozwiązania technologiczne, które generowały wysokie koszty eksploatacji budynków, co przy czynszach niezapewniających możliwości stałego monitorowania i prowadzenia na bieżąco niezbędnych remontów i działań modernizacyjnych skutkowało degradacją zasobów.

Kolejnym problemem, który ujawniał się w miarę upływu czasu, były nieodpowiadające zmieniającym się oczekiwaniom i potrzebom mieszkańców niskie stan- 
dardy techniczne budynków i jakość mieszkań (wielkość, wykończenie), a także brak powierzchni parkingowej. Podobnie coraz bardziej zauważalna i oceniana negatywnie była monotonia zabudowy, nadmierna skala budynków, brak udogodnień dla osób niepełnosprawnych czy wreszcie nieuwzględnianie wymogów ochrony środowiska. Te wady blokowisk przyczyniały się do powstawania rozmaitych negatywnych zjawisk społecznych, w tym do braku (lub znaczącego niedostatku) więzi [Rębowska 2006a, s. 5-6].

Bardzo niekorzystny dla stanu osiedli mieszkaniowych był okres „obniżania standardów założeń planowanych z równoczesnym rozwojem samowoli resortowej i indywidualnej", który - jak wskazuje A. Böhm - rozpoczął się w połowie lat 60 . XX w., a czemu towarzyszyło dalej podporządkowanie planowania przestrzennego priorytetom ilościowym, aż do okresu załamania gospodarczego w drugiej połowie lat 70 . W efekcie nastąpiło najpierw zubożenie, a następnie eliminowanie w praktyce czynników kompozycji, co prowadziło do powstawania „ułomnych" form urbanistycznych [Böhm 2006, s. 272]. Te problemy ujawniały się także na osiedlu Prądnik Czerwony, gdzie zbudowane w owym „najgorszym” okresie osiedle wielkopłytowych bloków zdominowało dawną zabudowę, tworząc w rezultacie chaotyczne zbiorowisko nieciekawych, powtarzalnych brył zabudowań. Warto podkreślić, że brakowało także odpowiednio zaaranżowanego otoczenia tych zabudowań, co nie zachęcało mieszkańców do traktowania tej przestrzeni jako „swojej”, a poszukiwanie takiej oswojonej przestrzeni przenosiło się często na teren ogródków działkowych ulokowanych na obrzeżach, które dla wielu ich użytkowników były jedyną szansą na praktykowanie „władania przestrzenią” poza ściśle prywatną przestrzenią mieszkania. Przejawiało się to m.in. w niezwykle rozbudowanych, choć często kontrowersyjnych formach wyrażania systemu wartości, upodobań estetycznych w sposobach wyposażania i organizacji przestrzeni ogródkowej.

\section{Pierwsze próby humanizowania osiedla Prądnik Czerwony}

Przez wiele lat popyt na mieszkania znacząco przewyższał ich podaż, zatem nie było praktycznie żadnej społecznej presji związanej z jakością czy walorami estetycznymi samych mieszkań, a także zespołów budynków czy osiedli. Dopiero w latach 80 . ubiegłego wieku pojawiły się pewne próby nie tylko wyrażania sprzeciwu, ale także podejmowania aktywności społecznej na rzecz poprawy środowiska mieszkalnego. W związku z początkami społecznych dyskusji nad kształtem państwa i gospodarki pojawiły się pewne działania zbiorowe o charakterze spontanicznym odnoszące się do różnych sfer rzeczywistości, m.in. ruchy ekologiczne, konsumenckie, działania związane z lokalnym środowiskiem 
życia itp. B. Jałowiecki opisuje kilka przykładów takich ruchów lokalnych ${ }^{2}$, które zrodziły się w wyniku niezgody na naruszanie cenionych wartości społecznych, takich jak sprawiedliwość, poszanowanie własności, prawa społeczności lokalnej do stanowienia o kierunkach rozwoju jej środowiska życia. Jak wynika z analizy wspomnianych przypadków, dążenia lokalne często popadały w kolizję z technokratycznym i biurokratycznym sposobem myślenia władz wyższego szczebla, pozorną fachowością ,urzędowych" ekspertów nieskorych do zmiany swojego zdania czy choćby rozważenia innych racji [Jałowiecki 1988, s. 21-22].

Prądnik Czerwony na początku okresu transformacji miał cechy typowe dla większości osiedli postkomunistycznych, co stanowiło znaczący bagaż w kontekście możliwości wprowadzania zmian w kierunku poprawiania jakości przestrzeni fizycznej i społecznej. Oceny osiedla na początku lat 90 . wyrażane przez profesjonalistów były raczej krytyczne. Brakom ładu urbanistycznego i estetycznego towarzyszyły objawy dezintegracji społecznej. Mieszkańcy Prądnika Czerwonego traktowali swoje osiedle przede wszystkim jako sypialnię. Na miejscu brakowało możliwości zaspokajania potrzeb codziennych i bardziej wyspecjalizowanych. W efekcie osłabiało to poczucie związków z najbliższym środowiskiem mieszkalnym, co skutkowało brakiem poczucia współodpowiedzialności i współuczestniczenia [Prawelska-Skrzypek 1992, s. 88-89].

Pierwsze inicjatywy na Czerwonym Prądniku zawarto w przygotowanym w latach 1983-1984 studium historyczno-krajobrazowym, a następnie w projekcie rekompozycji części osiedla. Jednocześnie mieszkańcy zaangażowali się we wspólną budowę sal katechetycznych przy kościele pw. Pana Jezusa Dobrego Pasterza i kościoła św. Jana Chrzciciela [Prawelska-Skrzypek 1992, s. 90]. Można powiedzieć, że podjęcie tych działań stworzyło podstawy do integracji społecznej wokół wspólnych celów.

Powstał zatem korzystny splot okoliczności związanych z pewnym ożywieniem społecznym, a jednocześnie z inicjatywą profesjonalistów (mieszkańców osiedla), którzy rozpoczęli prace studialne nad możliwościami „humanizowania przestrzeni", a także pobudzania aktywności społecznej.

Szczególnie ważna okazała się tu koncepcja sieci synergicznej opracowana przez A. Böhma (ówczesnego głównego architekta miasta i jednocześnie

${ }^{2}$ Chodzi tu o społeczny sprzeciw wobec procedury wywłaszczeń terenów pod budownictwo mieszkaniowe w Augustowie, podobny problem wystąpił w Rabce, protest przeciwko ustaleniom miejscowego planu zagospodarowania przestrzennego, a zwłaszcza zagęszczeniu zabudowy w Głoskowie, lokalizacji 2000 domów jednorodzinnych, co zmieniało charakter miejscowości w Starej Miłosnej, protest przeciwko przeprowadzeniu obwodnicy ulicą Krzyckiego w Warszawie, działania na rzecz odremontowania ocalałej w czasie wojny kamienicy i wykwaterowania uciążliwych współlokatorów na ulicy Noakowskiego w Warszawie, wreszcie protest przeciwko umiejscowieniu składowiska odpadów radioaktywnych w rejonie unikatowym przyrodniczo i w pobliżu obszarów mieszkalnych w Międzyrzeczu Wielkopolskim [Jałowiecki 1988, s. 16-20]. 
mieszkańca Prądnika Czerwonego). Zasada synergii, zakładająca, że dzięki występowaniu synergii elementy pewnego zbioru mogą stać się układem współdziałającym, opisywana najpierw w naukach przyrodniczych, została następnie zaadaptowana do rozważań nad działaniami grupowymi, wreszcie także, od co najmniej trzydziestu lat, do kształtowania koncepcji harmonijnego rozwoju w urbanistyce. Założenia, że do procesów porządkowania przestrzeni miasta można zastosować wnioski wynikające z tej koncepcji, stały się przedmiotem studiów teoretycznych [Böhm 1981], a następnie posłużyły do tworzenia praktycznych wskazówek odnośnie do rehabilitacji obszarów mieszkaniowych. „Koncepcja sieci synergicznej polega na nałożeniu na istniejący zbiór elementów (chaotyczny i niedostosowany do otoczenia) kanwy umożliwiającej harmonijne powiązanie owego zbioru z sąsiedztwem, a następnie przekształcenie go w spójną kompozycję krajobrazową" [Böhm 1987, s. 97].

Działania rekompozycyjne w stosunku do chaotycznego zbioru brył, jaki stanowiło typowe osiedle budowane w okresie socjalizmu, polegają na wyznaczaniu istotnych elementów całości przestrzennej, jaką są granice oraz „bramy” (miejsca łączące z sąsiednimi układami). W następnym etapie możliwe jest zaprojektowanie sieci wyznaczającej swoisty szkielet przyszłego porządku. Wypełnianie powstałych przestrzeni tworzy uporządkowany obszar z czytelną strukturą. Taka koncepcja rehabilitacji poprzez rekompozycję została opracowana dla potrzeb Prądnika Czerwonego w połowie lat 80. XX w.

Po zaprojektowaniu sieci synergicznej, opartej częściowo na istniejących drogach, w następnym etapie zaproponowano wizję porządkowania powstających elementów (wnętrz i placów). W ten sposób tworzy się złożony krajobraz, znacznie bardziej „miejski” w swoim charakterze, nawiązujący do unicestwionych przez proces budowania blokowiska dawnych zasobów kulturowych i krajobrazowych.

Ten projekt przez wiele lat pozostał wyłącznie koncepcją teoretyczną, ze względu na brak możliwości zrealizowania takich zamierzeń. Brakowało także dopełnienia w postaci rozbudowanego studium socjologicznego, wskazującego, po pierwsze, możliwości „rekompozycji społecznej”, a także, po drugie, zasoby sił społecznych, które mogłyby zostać przy okazji realizowania takiego projektu urbanistycznego uruchomione i wykorzystane. Przeprowadzone w 1991 r. badania geograficzno-społeczne skupiały się głównie na kwestiach percepcji walorów i niedostatków osiedla, a także na przestrzennych zachowaniach mieszkańców³

${ }^{3}$ Badania te związane były z projektem ulepszania osiedla rozpoczętego i inicjowanego przez mieszkańców we współpracy z duńskimi ekspertami [Prawelska-Skrzypek 1992-1993]. 


\section{4. ,Projekt duński”}

Początek transformacji przyniósł nowe możliwości w sferze humanizowania przestrzeni miasta. Znaczącą rolę odegrały tu procesy demokratyzacji, powstawanie organizacji pozarządowych, a także inne czynniki sprzyjające aktywizowaniu mieszkańców, w tym również przekształcenia samej spółdzielni mieszkaniowej. W 1990 r. mieszkańcy Prądnika Czerwonego podjęli starania na rzecz wyodrębnienia się z wielkiej spółdzielni („Wspólnota”) i powołania mniejszej, obejmującej tylko to osiedle. Zbiegło się to w czasie z komentowanym szeroko w mediach eksperymentem zaproponowanym władzom Krakowa przez duńskich architektów i urbanistów - przedstawicieli Ministerstwa Planowania Przestrzennego. Warto tu podkreślić, że w Danii - znacznie wcześniej niż w Polsce czy innych krajach należących do bloku sowieckiego, zaczęto rozwijać ideę smart city, miasta charakteryzującego się nastawieniem na równoważenie rozwoju, w sensie zarówno poszanowania i oszczędzania zasobów środowiskowych, jak i uruchamiania aktywności obywatelskiej (która zresztą jest niezbędnym czynnikiem pozwalającym na realizowanie tych zasad).

Spółdzielnia „Prądnik Czerwony” jako jedyna spółdzielnia mieszkaniowa w Krakowie odpowiedziała pozytywnie na zaproszenie duńskich ekspertów, decydując się na uruchomienie projektu we współpracy z mieszkańcami. Pozwoliło to na kontynuowanie rozpoczętych jeszcze w latach 80. prac studialnych, uzupełnionych przez ekspertyzy krajobrazowe, studia zasobów i wspomniane wyżej badania geograficzno-społeczne. Warto podkreślić, że polski zespół składał się w dużej mierze z mieszkańców osiedla, którzy jednocześnie posiadali odpowiednie przygotowanie profesjonalne, byli wśród nich architekci, urbaniści, geografowie społeczni.

Nowatorstwo projektu należy oceniać z ówczesnej perspektywy. Obecnie potrzeba udziału mieszkańców i zachęcanie ich do współpracy wykraczającej poza formalnie niezbędne konsultacje społeczne jest traktowana jako oczywistość, istnieją także liczne metody angażowania i włączania różnych grup społecznych (np. przez organizowanie rozmaitych typów warsztatów czy sondaż deliberacyjny). Na początku lat 90 . była to jednak w Polsce nowość, ciągle nieoswojona społecznie w szerszej skali i nieobudowana kulturowymi wzorami. Warto przy okazji podkreślić, że zastosowanie technik partycypacyjnych w procesach planowania przestrzennego i społecznego czy zachęcanie do brania udziału w budżecie partycypacyjnym wymaga starannego przygotowania stron - uczestników takich procesów. Niezbędny jest pewien poziom świadomości obywatelskiej, umiejętności współpracy, poczucie odpowiedzialności, umiejętności definiowania „dobra wspólnego" i swojej roli w jego osiąganiu. W okresie PRL-u, a także we wczesnym okresie transformacji brakowało takich kompetencji społecznych, 
zarówno po stronie, „władz”, jak i po stronie zbiorowości mieszkańców. Innym problemem był niedostatek organizacji pozarządowych czy ruchów obywatelskich nastawionych na rozwiązywanie problemów. Te niedostatki kapitału społecznego sprzyjały powstawaniu rozmaitych napięć społecznych, zwłaszcza w późniejszym okresie, kiedy brakowało już poczucia „pozytywnego wyróżnienia” powodowanego obecnością i zainteresowaniem mediów. Innego typu napięcia pojawiały się z kolei w końcowej fazie projektu, kiedy następowało zderzanie się oczekiwań $\mathrm{z}$ rezultatami.

Nowatorskie w tamtym okresie było zatem samo założenie, że projekt powstaje nie dla anonimowego „klienta”, ale dla współuczestniczącego „obywatela”. Aktywizacja społeczna prowadzona według wzorów duńskich obejmowała też wiele działań nakierowanych na najmłodszych mieszkańców osiedla. Nowością było też wyodrębnienie różnych typów przestrzeni na skali „,przestrzeń prywatna-przestrzeń publiczna". Jest to jeden z ważniejszych podziałów przestrzeni społecznej ze względu na kryterium specyfiki podejmowanych w danym obszarze działań, a także reguł i zasad zachowania, akceptowanego stopnia swobody i możliwości manifestowania własnych potrzeb i aspiracji. Posiadanie przestrzeni prywatnej czy półprywatnej (pozostającej we władaniu) jest ważnym elementem jakości życia w środowisku zamieszkania. W projekcie dla osiedla Prądnik Czerwony wydzielone zostały cztery strefy [Böhm 1993, s. 62]:

1) przestrzeń prywatna - tworząca, zwłaszcza dla mieszkańców parteru, swego rodzaju strefę ochronną obszaru „własnego”, jaką jest mieszkanie, utrudniająca niepożądane styczności. Tę strefę tworzyły ogródki pod oknami i przed wejściami do budynków;

2) przestrzeń półprywatna - odpowiada ona tradycyjnym dziedzińcom (jakich w blokach brakuje) - przestrzeń garaży, trzepaka, śmietnika i osłoniętego, przynależnego do bloku placyku zabaw dla dzieci;

3) przestrzeń półpubliczna - tworząca pewne obszary przestrzeni spotkań i nawiązywania relacji sąsiedzkich z mieszkańcami przyległych bloków; obejmuje głównie tereny rekreacyjne;

4) przestrzeń publiczna - najbardziej zewnętrzna strefa rozciągająca się wzdłuż ulic i placów, obejmująca usługi lokalne.

Zaproponowana przez autorów projektu propozycja miała na celu przekształcenie przestrzeni osiedla w spójną przestrzeń o miejskim charakterze, ale posiadającą skalę odpowiadającą potrzebie budowania wspólnotowych powiązań i potrzebie bezpieczeństwa.

Niestety, w trakcie podejmowanych działań wystąpiły rozmaite problemy związane ze znacznym stopniem zindywidualizowania oczekiwań i potrzeb, a także wynikające z braku odpowiedniej współpracy ze strony Rady Dzielnicy. Jeśli chodzi o pierwszą kwestię, to warto przypomnieć inne podobne przykłady 
braku umiejętności współpracy, dochodzenia do porozumienia w myśl zasad dobra wspólnego, wynikające m.in. z braku doświadczeń demokratycznych. $\mathrm{Na}$ początku transformacji w polskim społeczeństwie brakowało środowisk znających z własnego doświadczenia procedury demokratyczne. Kolejne generacje kształtowane przez rzeczywistość socjalistyczną pozbawione były takiego „treningu obywatelskiego”. Co gorsza, nawet z dzisiejszej perspektywy można powiedzieć, że ten nurt edukacji obywatelskiej został w znacznym stopniu zaniedbany. Choć powstaje wiele inicjatyw społecznych czy ruchów obywatelskich, to jednak w porównaniu z krajami o bardziej ustabilizowanej demokracji i długich tradycjach w tym względzie (jak na przykład USA czy kraje skandynawskie) liczne kręgi polskiego społeczeństwa nadal nie potrafią współpracować (choć potrafią skutecznie zorganizować swój sprzeciw).

Ważnym elementem projektu było przygotowanie koncepcji funkcjonowania osiedla zgodnie z zasadami zrównoważonego rozwoju. W opracowanym w 1993 r. raporcie zwrócono uwagę na konieczność oszczędzania energii, w tym opomiarowania sieci, zastosowania odpowiednich urządzeń, ale także używania odnawialnych źródeł energii.

Oszczędność wody - kolejny oczekiwany efekt projektu, miała być osiągana nie tylko poprzez uszczelnienie i unowocześnienie instalacji, ale także przez wprowadzanie obiegu zamkniętego, użycie wody deszczowej. Zgodnie z zasadami ochrony środowiska przewidywano wysoki stopień recyklingu, indywidualne sortowanie odpadów i zorganizowanie skutecznego systemu odbioru surowców w tórnych. Projekt zakładał też intensywną edukację ekologiczną, tak aby mieszkańcy w długiej perspektywie czasowej czuli się związani z ideą zrównoważonego rozwoju i by zostali trwale przekonani (zmotywowani) do konieczności zmiany stylu życia na bardziej ekologiczny [Action Plan... 1993, s. 6-7].

Założono, że Prądnik Czerwony będzie osiedlem modelowym, jednak te bardzo piękne i optymistyczne założenia okazały się w praktyce trudne do zrealizowania. Jak wskazywała A. Rębowska, oceniając stan osiedla w 2005 r., zrealizowano wiele prac remontowych i modernizacyjnych, zbudowano nowe drogi i systematycznie naprawiano istniejące. Nie wykonano jednak ambitnego planu budowy północnego parku, nie podjęto zabudowy mieszkalno-usługowej na tzw. ryneczku w centrum osiedla ani planowanej nadbudowy nad blokami o pięciu kondygnacjach. W części udało się zrealizować program oszczędności energii, ale już nie program segregacji odpadów i recyclingu [Rębowska 2006b, s. 107-110]. Wyniki badań zrealizowanych w 2006 r. wskazywały, że mieszkańcy osiedla są raczej zadowoleni ze swojego miejsca zamieszkania. Odsetek pozytywnych wskazań (bardzo zadowoleni i zadowoleni) wynosił 78,5\%, co świadczy o wysokim stopniu akceptacji. Czynniki wpływające na poziom zadowolenia to zarówno dobre rozwiązania infrastrukturalne (komunikacja, dostęp do usług itp.), 
jak i dobra ocena klimatu społecznego („ludzie są przyjaźni”) [Jerschina i in. 2012, s. 229-230].

\section{Obszary niezaspokojonych potrzeb na Prądniku Czerwonym}

Prądnik Czerwony jest jednym z kilkunastu osiedli krakowskich, które wytypowano w Instytucie Rozwoju Miast jako wymagające rewitalizacji. Charakterystyczne cechy tego osiedla sytuują je wśród ,przeciętnych”, choć na przykład dostęp do usług komercyjnych i infrastruktury publicznej jest tu lepszy niż średnio w Krakowie (tabela 1).

Tabela 1. Wskaźniki dla osiedla Prądnik Czerwony

\begin{tabular}{|c|c|c|c|c|}
\hline \multirow{3}{*}{ Lp. } & \multirow{3}{*}{ Wskaźnik } & \multicolumn{3}{|c|}{ Wartości } \\
\hline & & \multirow{2}{*}{$\begin{array}{l}\text { dla anali- } \\
\text { zowanego } \\
\text { obszaru }\end{array}$} & \multicolumn{2}{|c|}{ średnia } \\
\hline & & & $\begin{array}{c}\text { dla } 19 \\
\text { obszarów }\end{array}$ & $\begin{array}{c}\text { dla } \\
\text { Krakowa }\end{array}$ \\
\hline 1 & Średni wiek mieszkańców (os.) & 42,22 & 43,27 & 41,61 \\
\hline 2 & Odsetek osób w wieku poprodukcyjnym (\%) & 18,33 & 19,38 & 19,47 \\
\hline 3 & Odsetek osób pobierających zasiłki z MOPS (\%) & 0,03 & 0,07 & - \\
\hline 4 & $\begin{array}{l}\text { Odsetek inwalidów wśród pobierających zasiłek } \\
\text { z MOPS w Krakowie (\%) }\end{array}$ & 0,11 & 0,27 & - \\
\hline 5 & $\begin{array}{l}\text { Odsetek osób niepełnosprawnych wśród pobierających } \\
\text { zasiłek z MOPS w Krakowie (\%) }\end{array}$ & 0,95 & 1,89 & - \\
\hline 6 & $\begin{array}{l}\text { Odsetek osób z rodzin wieloosobowych pobierających } \\
\text { zasiłki z MOPS wśród pobierających zasiłki z MOPS } \\
\text { w Krakowie (\%) }\end{array}$ & 0,71 & 2,77 & - \\
\hline 7 & $\begin{array}{l}\text { Średni dochód miesięczny osób pobierających zasiłki } \\
\text { z MOPS (zł) }\end{array}$ & 226 & 184,75 & 182,01 \\
\hline 8 & $\begin{array}{l}\text { Średnie ceny transakcyjne na rynku wtórnym budow- } \\
\text { nictwa wielorodzinnego (zł) }\end{array}$ & 7500 & 6328 & - \\
\hline 9 & Odsetek gruntów stanowiących własność gminy (\%) & 77,61 & 63,69 & - \\
\hline 10 & Odsetek budynków stanowiących własność gminy (\%) & 0,00 & 8,84 & - \\
\hline 11 & Liczba obiektów handlowych (szt.) & 8 & 150,00 & - \\
\hline 12 & $\begin{array}{l}\text { Odsetek osób w wieku produkcyjnym pozostających } \\
\text { bez pracy }(\%)\end{array}$ & 0,04 & 0,05 & 0,04 \\
\hline 13 & $\begin{array}{l}\text { Odsetek osób w wieku do } 30 \text { lat pozostających bez } \\
\text { pracy }(\%)\end{array}$ & 0,016 & 0,02 & 0,02 \\
\hline 14 & Odsetek mężczyzn pozostających bez pracy (\%) & 0,022 & 0,02 & 0,02 \\
\hline
\end{tabular}


cd. tabeli 1

\begin{tabular}{|c|c|c|c|c|}
\hline \multirow{3}{*}{ Lp. } & \multirow{3}{*}{ Wskaźnik } & \multicolumn{3}{|c|}{ Wartości } \\
\hline & & \multirow{2}{*}{$\begin{array}{c}\text { dla anali- } \\
\text { zowanego } \\
\text { obszaru }\end{array}$} & \multicolumn{2}{|c|}{ średnia } \\
\hline & & & $\begin{array}{c}\text { dla } 19 \\
\text { obszarów }\end{array}$ & $\begin{array}{c}\text { dla } \\
\text { Krakowa }\end{array}$ \\
\hline 15 & $\begin{array}{l}\text { Odsetek bezrobotnych z wykształceniem podstawo- } \\
\text { wym i zawodowym }(\%)\end{array}$ & 0,023 & 0,03 & 0,04 \\
\hline 16 & $\begin{array}{l}\text { Powierzchnia terenów zielonych przypadających } \\
\text { na } 1 \text { mieszkańca }\left(\mathrm{m}^{2}\right)\end{array}$ & 9,8 & 16,38 & - \\
\hline 17 & Odsetek powierzchni biologicznie czynnej (\%) & 80,2 & 71,16 & - \\
\hline 18 & Odległość od parku miejskiego (m) & 100 & 112,00 & - \\
\hline 19 & $\begin{array}{l}\text { Odsetek terenów, gdzie normy hałasu są przekroczone } \\
(\%)\end{array}$ & 38,80 & 28,28 & - \\
\hline 20 & $\begin{array}{l}\text { Odsetek terenów, gdzie zagrożenie emisją hałasu dro- } \\
\text { gowego przekracza poziom } 55 \mathrm{~dB} \text { (pora nocna) (\%) }\end{array}$ & 25,23 & 15,68 & - \\
\hline 21 & $\begin{array}{l}\text { Odsetek terenów, gdzie zagrożenie emisją hałasu kole- } \\
\text { jowego przekracza poziom } 55 \mathrm{~dB} \text { (pora nocna) }(\%)\end{array}$ & 0,00 & 0,92 & - \\
\hline 22 & Odsetek zabudowy powstałej przed 1970 r. (\%) & 0,00 & 31,05 & - \\
\hline 23 & Średni wiek budynków (lata) & 17 & 35,00 & - \\
\hline 24 & Odsetek budynków objętych termomodernizacją (\%) & 95,2 & 88,48 & - \\
\hline 25 & $\begin{array}{l}\text { Powierzchnia terenów komunikacji na } 1 \text { mieszkańca } \\
\left(\mathrm{m}^{2}\right)\end{array}$ & 4,09 & 5,49 & - \\
\hline 26 & Liczba miejsc parkingowych na 1 mieszkańca (szt.) & 0,09 & 0,11 & - \\
\hline 27 & Średnia wysokość budynków (kond.) & 6,01 & 5,84 & - \\
\hline 28 & Gęstość zaludnienia (os./km²) & 20122 & 28246 & 2280 \\
\hline 29 & Intensywność zabudowy & 0,48 & 0,68 & - \\
\hline 30 & Odległość od centrum miasta $(\mathrm{km})$ & 4,90 & 5,96 & - \\
\hline 31 & $\begin{array}{l}\text { Odległość od przystanku komunikacji miejskiej (auto- } \\
\text { bus) (m) }\end{array}$ & 340 & 254 & - \\
\hline 32 & $\begin{array}{l}\text { Odległość od przystanku komunikacji miejskiej (tram- } \\
\text { waj) (m) }\end{array}$ & 2000 & 554 & - \\
\hline 33 & Odległość od szkoły podstawowej (m) & 373 & 276 & - \\
\hline 34 & Odległość od przedszkola (m) & 53 & 277 & - \\
\hline
\end{tabular}

Źródło: [Wielokryterialna... 2011, s. 69].

Wyraźnie brak na osiedlu terenów zielonych i - ogólnie rzecz biorąc - obszarów rekreacyjnych (co, jak wskazywano wyżej, było jednym z postulatów ,,projektu duńskiego", w którym obszary rekreacyjne zaplanowano jako część przestrzeni prywatnej poszczególnych bloków i przestrzeni wspólnie użytkowanej). 
Obserwacje w przestrzeni osiedla na wyodrębnionym obszarze wskazują na pewne zróżnicowanie terenu (rys. 1).

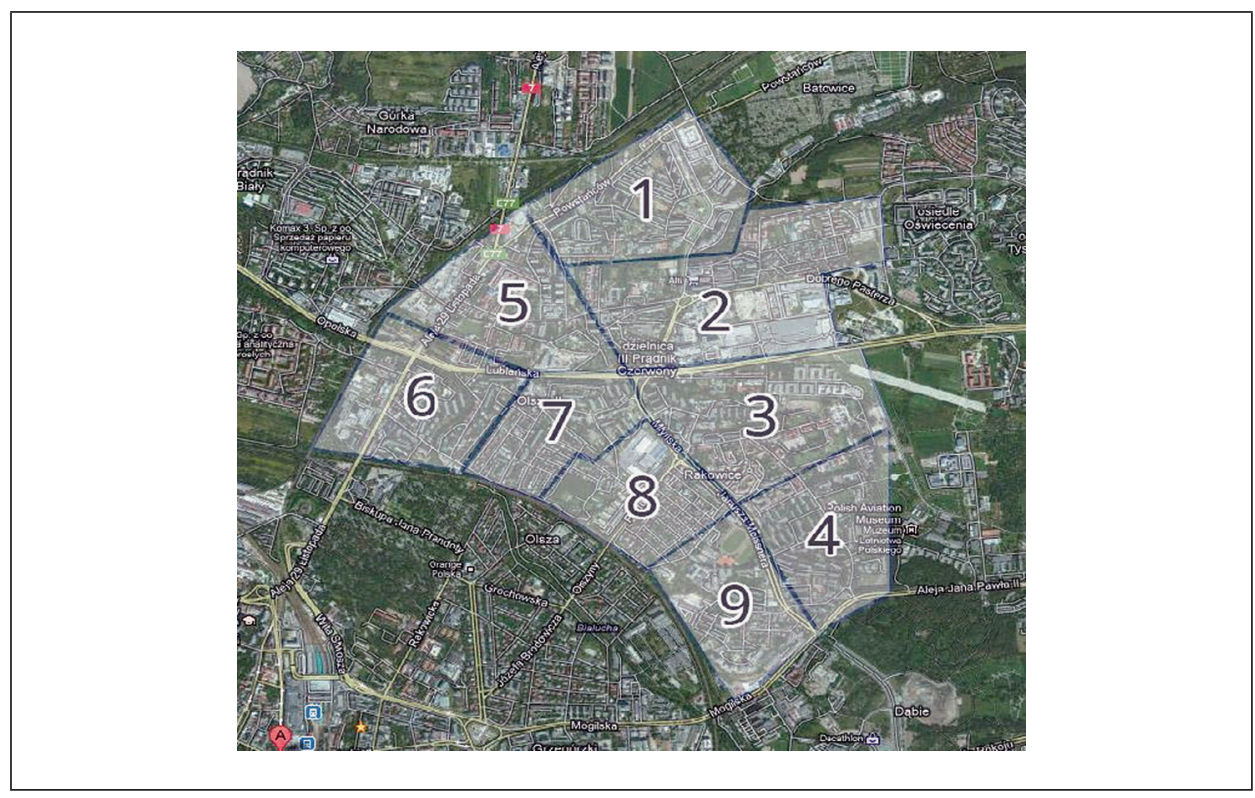

Rys. 1. Podział obserwowanego obszaru

Źródło: opracował Jakub Stępień na podstawie wyników obserwacji prowadzonych przez studentów (zob. przypis 1). W opracowaniu podziału obserwowanego obszaru wykorzystano fragment mapy Krakowa dostępnej w serwisie internetowym Google Maps, www.google.pl/maps.

W części 2 na rys. 1 można zauważyć niedostateczne wyposażenie terenu, brak właściwie miejsc pełniących funkcje przestrzeni publicznych, ułatwiających kontakty międzyludzkie, integrujących najmłodszych mieszkańców osiedla. Lepiej wyposażone są obszary 3 i 6, na których także stan infrastruktury służącej dzieciom jest lepszy.

Wnioski z obserwacji wskazują na brak miejsc spotkań, kawiarni, klubów, niedostatek zieleni urządzonej, czyli ważnych miejsc dla jakości życia mieszkańców osiedla. Charakterystyczne jest to, że obserwatorzy dostrzegli co najmniej kilka obszarów zaniedbanych, w tym zniszczone budynki, a także pustostany. Zauważalna jest różnica między stopniem zadbania o teren a rodzajem zabudowy, najlepiej jest w okolicy mniejszych domów (obszar 7), gorzej w okolicach wysokich bloków (2). Bardziej zadbana jest przestrzeń wymiany czy produkcji (komercyjna) niż część mieszkalna, zwłaszcza jeśli chodzi o przestrzenie międzyblokowe. Deterioracja przestrzeni miejskiej jest zazwyczaj bardzo silnie związana z występowaniem problemów społecznych i poczucia zagrożenia. Te wątki także 
pojawiają się w obserwacjach. Sygnałem potencjalnych zagrożeń są zauważone agresywne graffiti, wulgarne napisy odnoszące się przede wszystkim (choć nie tylko) do animozji zwolenników dwóch największych klubów piłkarskich w Krakowie.

Jak wynika ze sprawozdania radnego dzielnicy III [Sprawozdanie... 2012], zarejestrowane w raportach studenckich braki osiedla zostały zauważone przez władze lokalne. Jednym z ważnych celów społecznych w rozwoju tego obszaru była poprawa infrastruktury drogowej - te zadania zostały podjęte w latach 20072010, wraz z częściowym uwzględnieniem potrzeb osób niepełnosprawnych, co jest istotnym elementem budowania społeczności typu socially all inclusive (włączającej).

Uchwalenie Miejscowego planu zagospodarowania przestrzennego potoku Sudoł (co było przedmiotem „lobbowania” mieszkańców) umożliwiło podjęcie inwestycji parkowych. Jak wspomniano wcześniej, brak przestrzeni zielonych, rekreacyjnych jest jednym $\mathrm{z}$ istotnych problemów związanych z zapewnianiem wyższej jakości życia różnym grupom mieszkańców. $Z$ informacji prasowych z końca 2012 r. wynika, że mieszkańcy bardzo aktywnie włączają się we współpracę z innymi podmiotami. Obszar parku budowanego w rejonie ulicy Powstańców składał się z działek, które należały do różnych właścicieli, co potencjalnie utrudniało rozmowy i podejmowanie decyzji, jednak ostatecznie wykazali się oni dobrą wolą ${ }^{4}$.

Priorytety władz lokalnych obejmowały w okresie sprawozdawczym (20072010) wprowadzenie korzystnych dla mieszkańców Prądnika Czerwonego zmian do projektu nowego Studium zagospodarowania przestrzennego Miasta Krakowa, których realizacja ma skutkować poprawą komunikacji zbiorowej i wyprowadzeniem ruchu tranzytowego z Olszy i Prądnika Czerwonego na obwodnice miejskie. Inny ważny kierunek działania to aktywna polityka na rzecz bezpieczeństwa (w tym przeciwpowodziowego, przeciwpożarowego, ale także socjalnego). Władze dzielnicy dostrzegają też konieczność poprawy stopnia zaspokojenia potrzeb zarówno najmłodszych, jak i najstarszych mieszkańców, przez rozwijanie specjalnych programów i działania w sferze rozwoju infrastruktury społecznej. Chodzi tu m.in. o modernizację placów zabaw, budowę nowych skwerów i innych przestrzeni zieleni urządzonej, a także realizację projektu integracyjno-rekreacyjnego skierowanego do seniorów [Sprawozdanie... 2012].

Ważnym zasobem rozwojowym Prądnika Czerwonego są wskazywane wcześniej wartości składające się na kapitał kulturowy, które obejmują rozmaite elementy kultury symbolicznej i materialnej. Wartością przestrzenną Prądnika Czerwonego jest zróżnicowana zabudowa, na którą składają się ciągle jeszcze

${ }^{4}$ http://krakow.gazeta.pl/krakow/1,35812,12944245,Mieszkancy_walcza_o_parki_i_zielence_w_dzielnicach.html\#ixzz2MlAxftSs (data dostępu: 29.11.2012). 
obecne pozostałości życia „wiejskiego”, różnorodne formy zabudowy jednoi wielorodzinnej, osiedle wysokich bloków, a także elementy krajobrazu kulturowego, w tym kościoły oraz budownictwo zabytkowe. Do tych wartości nawiązują elementy trasy turystyczno-kulturowej Prądnika Czerwonego, która została opracowana przede wszystkim dla mieszkańców osiedla jako czynnik budowania i wzmacniania tożsamości i dumy lokalnej ${ }^{5}$. Jak wspomniano, na Prądniku Czerwonym zachowały się pewne fragmenty krajobrazu kulturowego, kilka obiektów o charakterze zabytkowym, a także enklawa zieleni wzdłuż potoku Sudoł ${ }^{6}$.

Te fragmenty przestrzeni mogą być określone jako „zwyczajne krajobrazy”, które przyczyniają się do kształtowania tożsamości zbiorowej. Te „Zwykłe”, z pozoru przeciętne miejsca tworzą historię i przestrzeń symboliczną, choć być może mają znaczenie tylko dla pewnych grup, czy nawet jednostek. Historia zapisywana w przestrzeni miejskiej jest równie różnorodna, jak różnorodne były i są środowiska tworzące zbiorowość miejską [Hayden 1997, s. 3]. Zatem nawet najbardziej skromne i zwykłe elementy przestrzeni mogą być, po pierwsze, znaczące i ważne dla określonych jednostek lub całych grup, po drugie - odgrywały (i odgrywają) istotną rolę w tworzeniu się miejskiego krajobrazu kulturowego, uzupełniając elementy przestrzeni odzwierciedlające wartości dominującej kultury. W tym znaczeniu obiekty proponowane jako przystanki czy punkty trasy turystyczno-kulturowej przyczyniają się do wzbogacania specyfiki miejsca, współtworzą lokalny kapitał rozwojowy.

Te zasoby mogą stać się podstawą osiągania ważnego społecznie celu, jakim jest wzmacnianie spójności społecznej i kapitału społecznego w skali osiedla. To warunek bardzo istotny dla uzyskiwania akceptacji dla rozmaitych zabiegów modernizacyjnych prowadzonych w środowisku mieszkalnym, które, w oczywisty sposób, nie mogą uwzględniać wszelkich szczegółowych oczekiwań i potrzeb każdego mieszkańca. Niezbędny jest zatem odpowiednio wysoki poziom zaufania, zarówno społecznego nieformalnego, jak i obywatelskiego (uczestnictwo w stowarzyszeniach, udział w wyborach lokalnych) czy zaufania do instytucji (w tym do profesjonalistów). Nieformalne zaufanie społeczne opiera się także na zasadzie wzajemności i na poczuciu więzi z miejscem zamieszkania [Frykowski 2004, s. 172] - odgrywa zatem ważną rolę w procesach przemian społecznych i przestrzennych na osiedlu, choć warto zaznaczyć, że istnieje tu niebezpieczeństwo wykorzystywania go do obrony partykularnych interesów.

5 Trasa turystyczno-kulturowa została opracowana przez radnego Dzielnicy III - Dominika Jaśkowca oraz Wiesława Barczewskiego z Towarzystwa Prądnickiego, obejmuje ona ponad 20 obiektów i miejsc.

${ }^{6}$ http://dzielnica3.ochalek.net/o-dzielnicy/trasy-turystyczne/ (data dostępu: 7.01.2013). 


\section{Uwagi końcowe}

Blokowiskom, jak wskazują na to wyniki prowadzonych badań, brakuje wielu - ważnych ze społecznego punktu widzenia i dla psychicznego dobrostanu mieszkańców - cech, zarówno przestrzennych, jak i społecznych. Chodzi tu o przekroczenie skali, czyli nadmiar wysokich budynków i zbyt duże ich zagęszczenie, jak też brak dostatecznej liczby terenów zieleni urządzonej o różnym stopniu ,prywatności" (związanej z odległością od bloku, infrastrukturą, pewnym oddzieleniem od otoczenia, czy wreszcie z możliwością decydowania o kształcie i wyposażeniu takich miejsc). Ważne są też kwestie funkcjonalności przestrzeni przyczyniającej się do sprawnego działania elementów struktur miejskich zapewniającej poczucie wygody [Ziobrowski 1992, s. 46-47].

Przeprowadzone badania pozwalają wyciągnąć wniosek, że dla dobrego funkcjonowania osiedla niezbędne są działania na rzecz wieloaspektowego równoważenia jego rozwoju. Chodzi tu zatem, po pierwsze, o równowagę pomiędzy przemianami i trwaniem pewnych istotnych dla danej zbiorowości elementów przestrzennych, społecznych i kulturowych. Drugim istotnym obszarem jest osiąganie równowagi między sztucznymi (tworzonymi przez człowieka) i naturalnymi elementami środowiska mieszkalnego. Kolejna kwestia dotyczy zachowania różnorodności krajobrazu, przeciwdziałania monotonii typowej m.in. dla postsocjalistycznych blokowisk. Równowaga między funkcjonowaniem miasta jako całości i wzmacnianiem lokalnych tożsamości opartych na tradycjach, swoistości krajobrazu kulturowego, lokalnej gospodarce itd. jest następnym ważnym celem rozwojowym środowiska mieszkalnego.

Wskazane wyżej przykłady humanizowania środowiska społecznego i przestrzennego osiedla Prądnik Czerwony obejmują kolejne próby zdefiniowania i realizowania najważniejszych celów społecznych ważnych dla mieszkańców tego obszaru. Należy mieć nadzieję, że podjęte działania związane z rehabilitacją 19 krakowskich blokowisk, wśród których znalazł się także Prądnik Czerwony, przyniosą zadowalające mieszkańców rezultaty, tym bardziej że na przestrzeni ponad dwóch dekad od rozbudowanego - jeśli chodzi o cele społeczne - ,projektu duńskiego" potrzeby i aspiracje mieszkańców znacznie wzrosły.

\section{Literatura}

Action Plan, Rehabilitation of the Urban Environment in Prqdnik Czerwony, Cracow. A Polish-Danish Pilot Project [1993], 25 May, Kraków, materiały powielone.

Bieniarzówna J., Małecki J.M. [1985], Dzieje Krakowa. Kraków w latach 1796-1918, t. 3, Wydawnictwo Literackie, Kraków. 
Böhm A. [1981], O budowie i synergii wnętrz urbanistycznych, Wydawnictwo Politechniki Krakowskiej, Kraków.

Böhm A. [1986], Najstarsza dzielnica willowa, „Magazyn Kulturalny”, nr 1.

Böhm A. [1987], Koncepcja sieci synergicznej dla rekompozycji krajobrazu osiedla blokowego, Teka Komisji Urbanistyki i Architektury, T. XXI.

Böhm A. [1993], Rehabilitacja osiedla Prqqnik Czerwony [w:] Gospodarka gruntami. Wybrane problemy, red. A. Böhm, Z. Ziobrowski, Mistia, Kraków.

Böhm A. [2006], Planowanie przestrzenne dla architektów krajobrazu. O czynniku kompozycji, Wydawnictwo Politechniki Krakowskiej, Kraków.

Broniewski S. [1970], Igraszki z czasem, Wydawnictwo Literackie, Kraków.

Demel J. [1957], Kraków na przełomie XIX i XX wieku [w:] Kraków, studia nad rozwojem miasta, red. J. Dąbrowski, Wydawnictwo Literackie, Kraków.

Estreicherówna E. [1968], Życie towarzyskie i obyczajowe Krakowa w latach 1848-1863, Wydawnictwo Literackie, Kraków.

Frykowski M. [2004], Zaufanie i kapitał społeczny w przestrzeni miejskiej Łodzi [w:] Wokót socjologii przestrzeni, red. A. Majer, P. Starosta, Wydawnictwo Uniwersytetu Łódzkiego, Łódź.

Hayden D. [1997], The Power of Place. Urban Landscapes as Public History, The MIT Press, Cambridge, Massachusetts.

Jałowiecki B. [1988], Lokalne ruchy społeczne w perspektywie procesów globalnych [w:] Problemy rozwoju lokalnego, red. P. Dutkiewicz, G. Gorzelak, UW IGP, Warszawa.

Jerschina J. i in. [2012], Badania poczucia bezpieczeństwa mieszkańców Prqdnika Czerwonego w Krakowie ze szczególnym uwzględnieniem wpływu zmian architektonicznych i technicznych na poziom lęku przed przestępczościa [w:]: Zapobieganie przestępczości przez kształtowanie przestrzeni, red. J. Czapska, Wydawnictwo Uniwersytetu Jagiellońskiego, Kraków.

Kraków a wsie podmiejskie w relacjach etnograficznych sprzed stu lat [1993], wybór i komentarz E. Fryś-Pietraszkowa [w:] Kraków. Przestrzenie kulturowe, red. J. Bujak i in., Platan, Kraków.

Mydel R. [1994], Rozwój urbanistyczny Miasta Krakowa po drugiej wojnie światowej, Secesja, Kraków.

Prawelska-Skrzypek G. [1992], Gra o osiedle - Prqdnik Czerwony w Krakowie [w:] Gra o miasto, red. B. Jałowiecki, Biuletyn KPZK, nr 157.

Prawelska-Skrzypek G. [1992-1993], Mikroskalowe badania społeczne dla potrzeb ulepszenia osiedla mieszkaniowego Prqdnik Czerwony w Krakowie, Folia Geographica, series Geographica-Oeconomica, vol. XXV-XXVI.

Purchla J. [1990], Jak powstał nowoczesny Kraków, Wydawnictwo Literackie, Kraków.

Rębowska A. [2006a], Rehabilitacja blokowisk w świetle badań terenowych na wybranych osiedlach [w:]: Strategie rehabilitacji „blokowisk”, red. A. Rębowska, Instytut Rozwoju Miast, Kraków.

Rębowska A. [2006b], Wprowadzenie [w:] Strategie rehabilitacji blokowisk, red. J. Jeżak $\mathrm{i}$ in., Instytut Rozwoju Miast, Kraków.

Sprawozdanie radnego Dzielnicy III, Dominika Jaśkowca [2012], http://www.jaskowiec. strefa.pl (data dostępu: 29.11.2012).

Wielokryterialna analiza dziewiętnastu osiedli zabudowy blokowej położonych na terenie gminy miejskiej Kraków [2011], Instytut Rozwoju Miast, Kraków. 
Ziobrowski Z. [1992], Mierniki jakości przestrzeni miejskiej, Instytut Gospodarki Przestrzennej i Komunalnej, Kraków.

\section{Social Objectives in the Processes of Urban Change - The Example of Cracow's Prądnik Czerwony District}

The article presents the processes of the humanisation of Cracow's Prądnik Czerwony district. It discusses activities aimed at formulating and implementing social goals in the process of improving the district's spatial and social structure. Important stages in the socio-spatial development of this area are presented as well as actions undertaken thanks to the inspiration of the residents and city authorities working with various institutions. Existing traditions, cultural resources, places and buildings that potentially could have been centers of social aggregation were partially destroyed. Some were rejected because they did not work in the new environment. After many years some of these places seem to be ,regaining power", in the sense that they have become the foundation for certain social ties and common action.

Keywords: housing, Prądnik Czerwony, social goals, smart city, urban space. 